\title{
Synthesis and Antioxidant Activity of Novel Series of Naphthoquinone Derivatives Attached to Benzothiophene Moiety
}

\section{Moustafa A Gouda ${ }^{1,2 *}$, Hadeer Fakhr Eldien ${ }^{1}$, Margret M Girges ${ }^{1}$ and Moged A Berghot ${ }^{1}$}

${ }^{1}$ Chemistry Department, Faculty of Science, Mansoura University, Mansoura 35516, Egypt

${ }^{2}$ Department of Chemistry, Faculty of Science and Arts, Ulla, Taibah University, KSA

\begin{abstract}
A series of aryl azonaphthoquinones 8a-e were obtained via coupling of the corresponding diazonium salts 7a-c with naphthoquinones 2 or 3 in pyridine. Moreover, treatment of 5 with $6 a, b$ in ethanol containing potassium carbonate afforded the corresponding enaminones $9 a, b$, respectively. Furthermore, heating of 6a with 2-hydroxy-3-((piperidn1-yl)methyl)naphthalene-1,4-dione 10 in $\mathrm{EtOH} / \mathrm{AcOH}$ or sodium 3,4-dihydro-3,4-dioxonaphthalene-1-sulphonate 1 in $\mathrm{MeOH} / \mathrm{H}_{2} \mathrm{O}$ afforded the corresponding enaminones 11 and 12, respectively. The newly synthesized compounds were screened for their antioxidant activity. Compounds $8 \mathrm{~b} 89.87,9 \mathrm{a}(89.93 \%)$ and $9 \mathrm{~b}(95.97 \%)$ exhibited promising activities. On the other hand compounds $8 b, 9 a, 9 b, 11$ and 12 have the ability to protect DNA from the damage induced by bleomycin.
\end{abstract}

Keywords: Naphthoquinone; Thiophene; ABTS antioxidant; Bleomycin-dependent DNA damage

\section{Introduction}

Naphthoquinone derivatives have attracted continuing interest over the years because of the use of its ring system as important core structure in many drug substances and reported to cover wide range of pharmacological applications $[1,2]$. Furthermore, quinones, particularly 1,4-naphthoquinones are widely distributed phenolic compounds in nature such naphthoquinones are reported to exhibit diverse pharmacological properties like antibacterial [3], antifungal, antiviral, anti-inflammatory antipyretic properties and anticancer activity [4]. These quinones have the ability to induce oxidative stress which is responsible for initiation of tissue damage selectively in tumor cells and this seems to be a promising approach for targeting cancer cells [5]. Moreover many biological properties for 2-aminothiophene derivatives have been reported, such as $\mathrm{A} 1$ adenosine receptor allosteric enhancers [6,7], antifungal [8], antibacterial [9], antiproliferative [8], anti-inflammatory [10], antitumor and anti-HIV activities [7]. In view of the above mention and as a part of our continuous efforts towards the development of more potent antioxidant agents [11-15], it was thought of interest to combine the above mentioned boilable rings together in a molecular framework to investigate the additive effect of these rings towards antioxidant activities.

\section{Experimental}

\section{Instruments and methods}

All melting points are in degree centigrade (uncorrected) and were determined on Gallenkamp electric melting point apparatus. Thin layer chromatography (TLC) was carried out on silica gel $60 \mathrm{~F}_{254}$ precoated aluminum sheets. The IR spectra were recorded $(\mathrm{KBr})$ on a Mattson 5000 FTIR Spectrophotometer $\left(\lambda, \mathrm{cm}^{-1}\right)$ at the Microanalytical Unit, Faculty of Science, Mansoura University. The ${ }^{1} \mathrm{H}-\mathrm{NMR}$ spectra were determined on a Varian XL $200 \mathrm{MHz}$ in dimethylsulfoxide (DMSO) and chloroform as solvents using tetramethylsilane (TMS) as internal standard at the Microanalytical Center, Faculty of Science, Cairo University. ${ }^{13} \mathrm{C}$-NMR spectra were recorded on JEOL-ECA500 (National Research Center, Egypt). The mass spectra (EI) were recorded on $70 \mathrm{eV}$ with Kratos MS equipment at the Microanalytical Center, Cairo University, Giza, Egypt. Elemental analyses (C, H and N) were carried out at the Microanalytical Center, Cairo University, Giza, Egypt. The elemental analyses were found to agree favorably with the calculated values. Biological activities were carried at Pharmacognosy
Department, Faculty of Pharmacy, Mansoura University, Mansoura, Egypt.

General procedure for the synthesis of 3-[(3-substituted-4,5,6,7tetrahydrobenzo[b] thiophen-2-yl)diazenyl $]$ naphthalene-1,4-diones 8a-e: A well stirred solution of 2 -aminothiophens $6 \mathrm{a}-\mathrm{c}(0.005$ mole) in concentrated $\mathrm{HCl}(3.6 \mathrm{~mL})$ and $\mathrm{H}_{2} \mathrm{O}(1 \mathrm{~mL})$ was cooled in an ice-bath and diazotized with the solution of $\mathrm{NaNO}_{2}(0.345 \mathrm{~g}, 0.005$ mole) in $\mathrm{H}_{2} \mathrm{O}(2 \mathrm{~mL})$. The cold diazonium solution was added slowly to a well stirred solution of 2-hydroxynaphthalene-1,4-dione $(0.87 \mathrm{~g}$, 0.005 mole) or 2-methoxynaphthalene-1,4-dione ( $0.94 \mathrm{~g}, 0.005$ mole) in pyridine $(20 \mathrm{~mL})$. The reaction mixture was stirred for further $2 \mathrm{~h}$. The crude product was filtered off, dried well and crystallized from the appropriate solvent to give compounds 8a-e.

(E)-Ethyl 2-((3-hydroxy-1,4-dioxo-1,4-dihydronaphthalen-2-yl) diazenyl)-4,5,6,7-tetrahydro-benzo[b] thiophene-3-carboxylate (8a) Yield $(0.83 \mathrm{~g}, 96 \%)$; crystallization from ethanol; brown powder; m.p. $214^{\circ} \mathrm{C}$. IR(KBr): $v / \mathrm{cm}^{-1}=3434(\mathrm{br}, \mathrm{OH}), 2933(\mathrm{C}-\mathrm{H}$ aliphatic), 1673 (br. 3CO), $1498(\mathrm{~N}=\mathrm{N}) ;{ }^{1} \mathrm{H}-\mathrm{NMR}\left(200 \mathrm{MHz}, \mathrm{CDCl}_{3}\right) \delta(\mathrm{ppm}): 1.45(\mathrm{t}, 3 \mathrm{H}$, $\left.\mathrm{CH}_{3}, J=6.9 \mathrm{~Hz}\right), 1.78-1.82\left(\mathrm{~m}, 4 \mathrm{H}, \mathrm{C}_{5}-2 \mathrm{H}, \mathrm{C}_{6}-2 \mathrm{H}\right), 2.73-2.85(\mathrm{~m}, 4 \mathrm{H}$, $\left.\mathrm{C}_{4}-2 \mathrm{H}, \mathrm{C}_{7}-2 \mathrm{H}\right), 4.52\left(\mathrm{q}, 2 \mathrm{H}, \mathrm{CH}_{2}, J=6.9 \mathrm{~Hz}\right), 7.79-8.40(\mathrm{~m}, 4 \mathrm{H}, \mathrm{Ar}-\mathrm{H})$, $13.52(\mathrm{br}, 1 \mathrm{H}, \mathrm{OH}) ;{ }^{13} \mathrm{C}-\mathrm{NMR}\left(100 \mathrm{MHz}, \mathrm{DMSO}-d_{6}\right) \delta(\mathrm{ppm}): 183.2$ 181.1, 165.3, 155.8, 145.7, 135.0, 133.0, 132.6, 130.4, 129.3, 128.4, 126.9, $126.4,120.4,88.9,59.8,25.8,24.1,22.3,22.1,13.8$. MS (EI, 70 ev) $\mathrm{m} / z$ $(\%)=408\left(\mathrm{M}^{+}-2,0.4\right), 335$ (3.1), 282 (1.9), 225 (9.7), 224 (62.5), 220 (31.3), 188 (59.2), 178 (100.0). Anal. Calcd. for $\mathrm{C}_{21} \mathrm{H}_{18} \mathrm{~N}_{2} \mathrm{O}_{5} \mathrm{~S}$ (410.09): C, 61.45; H, 4.42; N, 6.83\%. Found: C, 61.48; H, 4.37; N, 6.88\%.

(E)-2-((3-Hydroxy-1,4-dioxo-1,4-dihydronaphthalen-2-yl) diazenyl)-4,5,6,7-tetra-hydrobenzo[b] thiophene-3-carboxamide (8b): Yield (0.35 g, 40\%); crystallization from ethanol; brown powder; m.p $285^{\circ} \mathrm{C}$. IR $(\mathrm{KBr}): v / \mathrm{cm}^{-1}=3446$ (br., $\left.\mathrm{OH}\right), 3334\left(\mathrm{NH}_{2}\right), 2926(\mathrm{C}-$

*Corresponding author: Moustafa A Gouda, Chemistry Department, Faculty of Science, Mansoura University, Mansoura 35516, Egypt, Tel: (+2050) 6432235, Fax (+2050)2246781; E-mail: dr_mostafa_chem@yahoo.com

Received May 10, 2013; Accepted June 14, 2013; Published June 16, 2013

Citation: Gouda MA, Eldien HF, Girges MM, Berghot MA (2013) Synthesis and Antioxidant Activity of Novel Series of Naphthoquinone Derivatives Attached to Benzothiophene Moiety. Med chem 3: 228-232. doi:10.4172/2161-0444.1000143

Copyright: (C) 2013 Gouda MA, et al. This is an open-access article distributed under the terms of the Creative Commons Attribution License, which permits unrestricted use, distribution, and reproduction in any medium, provided the original author and source are credited. 
$\mathrm{H}$, aliphatic), 1673, $1639(3 \mathrm{CO}), 1486(\mathrm{~N}=\mathrm{N}) ;{ }^{1} \mathrm{H}-\mathrm{NMR}(200 \mathrm{MHz}$, DMSO- $\left.d_{6}\right) \delta(\mathrm{ppm}): 1.77-1.90\left(\mathrm{~m}, 4 \mathrm{H}, \mathrm{C}_{5}-2 \mathrm{H}, \mathrm{C}_{6}-2 \mathrm{H}\right), 2.35-2.51(\mathrm{~m}$, $\left.4 \mathrm{H}, \mathrm{C}_{4}-2 \mathrm{H}, \mathrm{C}_{7}-2 \mathrm{H}\right), 3.41$ (br., $\left.2 \mathrm{H}, \mathrm{NH}_{2}\right), 7.87-8.08(\mathrm{~m}, 4 \mathrm{H}, \mathrm{Ar}-\mathrm{H}), 13.49$ (br., $1 \mathrm{H}, \mathrm{OH})$. MS (EI, $70 \mathrm{ev}) \mathrm{m} / z(\%)=386\left(\mathrm{M}^{+}+5,1.0\right), 359(12.6)$, 345 (100.0). Anal. Calcd. for $\mathrm{C}_{19} \mathrm{H}_{15} \mathrm{~N}_{3} \mathrm{O}_{4} \mathrm{~S}$ (381.08): C, 59.83; H, 3.96; $\mathrm{N}, 11.02 \%$. Found: C, 59.79; H, 3.93; N, 11.06\%.

(E)-2-((3-Hydroxy-1,4-dioxo-1,4-dihydronaphthalen-2-yl) diazenyl)-4,5,6,7-tetra hydrobenzo[b]thiophene-3-carbonitrile (8c): Yield (0.54 g, 62\%); crystallization from ethanol; brown powder; m.p. $>320^{\circ} \mathrm{C}$. IR (KBr): $v / \mathrm{cm}^{-1}=3417$ (br., OH), 2931, 2858 (C-H, aliphatic), $2189(\mathrm{CN}), 1672,1629,(2 \mathrm{CO}), 1452(\mathrm{~N}=\mathrm{N}) ;{ }^{1} \mathrm{H}-\mathrm{NMR}(200 \mathrm{MHz}$, DMSO- $\left.d_{6}\right) \delta(\mathrm{ppm}): 1.71-1.80\left(\mathrm{~m}, 4 \mathrm{H}, \mathrm{C}_{5}-2 \mathrm{H}, \mathrm{C}_{6}-2 \mathrm{H}\right), 2.68-2.75(\mathrm{~m}$, $\left.4 \mathrm{H}, \mathrm{C}_{4}-2 \mathrm{H}, \mathrm{C}_{7}-2 \mathrm{H}\right), 7.21-8.23(\mathrm{~m}, 4 \mathrm{H}, \mathrm{Ar}-\mathrm{H}), 13.50$ (br., $\left.1 \mathrm{H}, \mathrm{OH}\right)$ ${ }^{13} \mathrm{C}-\mathrm{NMR}\left(125 \mathrm{MHz}, \mathrm{DMSO}-d_{6}\right) \delta$ (ppm):183.2, 181.1, 159.4, 153.1, $135.1,133.1,132.7,132.3,129.3,127.0126 .3,120.5,120.1,88.6,115.59$ , 26.5, 25.5, 22.2, 22. 1. MS (EI, $70 \mathrm{ev)} \mathrm{m} / z(\%)=363\left(\mathrm{M}^{+}, 3.0\right), 337$ (12.0), 310 (8.0), 280 (10.0), 266 (30.0), 240 (15.2), 223 (10.4), 211 (8.2), 199 (24.0), 188 (39.0), 173 (60.3), 161 (29.3), 150 (84.0), 145 (46.0), 134 (39.1), 99 (47.0), 98 (100.0). Anal. Calcd for $\mathrm{C}_{19} \mathrm{H}_{13} \mathrm{~N}_{3} \mathrm{O}_{3} \mathrm{~S}$ (363.07): C, $62.80 ; \mathrm{H}, 3.61 ; \mathrm{N}, 11.56 \%$. Found: C, 62.77; H, 3.56; N, $11.59 \%$.

(E)-Ethyl 2-((3-methoxy-1,4-dioxo-1,4-dihydronaphthalen-2yl)diazenyl)-4,5,6,7-tetrahydrobenzo[b] thiophene-3-carboxylate (8d): Yield (0.47 g, 50\%); crystallization from ethanol; brown powder; m.p. $191^{\circ} \mathrm{C}$. IR $(\mathrm{KBr}): v / \mathrm{cm}^{-1}=2933(\mathrm{C}-\mathrm{H}$, aliphatic), $1714,1673(3 \mathrm{CO})$, $1459(\mathrm{~N}=\mathrm{N}) ;{ }^{1} \mathrm{H}-\mathrm{NMR}\left(200 \mathrm{MHz}, \mathrm{CDCl}_{3}\right) \delta(\mathrm{ppm}): 1.36\left(\mathrm{t}, 3 \mathrm{H}, \mathrm{CH}_{3}, J\right.$ $=7.2 \mathrm{~Hz}), 1.81-1.84\left(\mathrm{~m}, 4 \mathrm{H}, \mathrm{C}_{5}-2 \mathrm{H}, \mathrm{C}_{6}-2 \mathrm{H}\right), 2.57-2.85\left(\mathrm{~m}, 4 \mathrm{H}, \mathrm{C}_{4}-2 \mathrm{H}\right.$, $\left.\mathrm{C}_{7}-2 \mathrm{H}\right), 3.91\left(\mathrm{~s}, 3 \mathrm{H}, \mathrm{OCH}_{3}\right), 4.30\left(\mathrm{q}, 2 \mathrm{H}, \mathrm{CH}_{2}, J=7.2 \mathrm{~Hz}\right), 7.26-8.41(\mathrm{~m}$, $4 \mathrm{H}, \mathrm{Ar}-\mathrm{H})$; MS (EI, $70 \mathrm{ev}) \mathrm{m} / z(\%)=426\left(\mathrm{M}^{+}+2,0.2\right), 424\left(\mathrm{M}^{+}, 0.4\right)$, 343 (1.3), 287 (60.0), 258 (17.9), 241 (29.8), 224 (69.2), 221 (20.8), 188 (26.2), 178 (100.0). Anal. Calcd for $\mathrm{C}_{22} \mathrm{H}_{20} \mathrm{~N}_{2} \mathrm{O}_{5} \mathrm{~S}$ (424.11): C, 62.25; $\mathrm{H}$, $4.75 ; \mathrm{N}, 6.60 \%$. Found: C, 62.29; H, 4.70; N, 6.66\%.

(E)-2-((3-Methoxy-1,4-dioxo-1,4-dihydronaphthalen-2-yl) diazenyl)-4,5,6,7-tetra hydrobenzo[b]thiophene-3-carboxamide (8e): Yield (0.43 g, 46\%); crystallization from ethanol; brownish black powder; m.p. $225^{\circ} \mathrm{C}$. IR (KBr): $v / \mathrm{cm}^{-1}=3440$ (br., $\left.\mathrm{NH}_{2}\right), 2925$ (C-H aliphatic), 1652 (br., 3CO), $1454(\mathrm{~N}=\mathrm{N}) ;{ }^{1} \mathrm{H}-\mathrm{NMR}(200 \mathrm{MHz}$, DMSO- $\left.d_{6}\right) \delta(\mathrm{ppm}): 1.52-1.85\left(\mathrm{~m}, 4 \mathrm{H}, \mathrm{C}_{5}-2 \mathrm{H}, \mathrm{C}_{6}-2 \mathrm{H}\right) ; 2.72-2.88(\mathrm{~m}$, $\left.4 \mathrm{H}, \mathrm{C}_{4}-2 \mathrm{H}, \mathrm{C}_{7}-2 \mathrm{H}\right), 3.86\left(\mathrm{~s}, 3 \mathrm{H}, \mathrm{OCH}_{3}\right), 7.25-8.12(\mathrm{~m}, 4 \mathrm{H}, \mathrm{Ar}-\mathrm{H}), 8.62$ (br., $\left.2 \mathrm{H}, \mathrm{NH}_{2}\right) ;{ }^{13} \mathrm{C}-\mathrm{NMR}\left(125 \mathrm{MHz}, \mathrm{DMSO}-d_{6}\right) \delta$ (ppm): 183.2, 181.0, 158.7, 153.1, 135.1, 133.1, 132.6, 132.0, 129.3, 126.7, 126.2, 120.2, 120.1, $115.9,87.2,55.2,24.1,23.7,23.3,22.1$. MS (EI, $70 \mathrm{ev)} \mathrm{m} / z(\%)=394$ $\left(\mathrm{M}^{+}-1,1.3\right), 348$ (7.1), 329 (40.4), 313 (25), 255 (23.1), 196 (23.1), 191 (57.7), 188 (100.0). Anal. Calcd. for $\mathrm{C}_{20} \mathrm{H}_{17} \mathrm{~N}_{3} \mathrm{O}_{4} \mathrm{~S}$ (395.09): C, 60.75; H, 4.33 ; N, 10.63\%. Found: C, 60.72; H, 4.38; N, $10.61 \%$.

General procedure for the synthesis of 2-((3-substituted4,5,6,7-tetrahydrobenzo[b] thiophen-2-yl)amino)-3-methoxynaphthalene-1,4-diones 9a, b: To a solution of each of 2-bromo-3-methoxynaphthalene-1,4-dione (5) $(1.33 \mathrm{~g}, 5 \mathrm{mmol})$ in ethanol $(50 \mathrm{~mL})$ and ethyl 2-amino-4,5,6,7-tetrahydrobenzo[b]thiophene-3-carboxylate (6a) (1.12 g, $5 \mathrm{mmol})$ or 2-amino-4,5,6,7-tetrahydrobenzo[b]thiophene-3-carboxamide (6b) $(0.98 \mathrm{~g}, 5 \mathrm{mmol})$ and potassium carbonate $(0.69 \mathrm{~g}, 5 \mathrm{mmol})$ were added. The reaction mixture was refluxed for 8 $\mathrm{h}$ and left to cool at room temperature. The obtained solid product was filtered off, dried and crystallized from ethanol to give compounds 9a, b, respectively.

Ethyl 2-((3-methoxy-1,4-dioxo-1,4-dihydronaphthalen-2-yl) amino)-4,5,6,7-tetra-hydrobenzo[b]thiophene-3-carboxylate (9a): Yield $(0.89 \mathrm{~g}, 80 \%)$; crystallization from ethanol; brown powder; m.p. $101^{\circ} \mathrm{C}$. IR (KBr): $v / \mathrm{cm}^{-1}=3297(\mathrm{NH}), 2935$ (C-H, aliphatic), 1646 (br., 3CO); ${ }^{1} \mathrm{H}-\mathrm{NMR}\left(200 \mathrm{MHz}, \mathrm{CDCl}_{3}\right) \delta$ (ppm): $1.34\left(\mathrm{t}, 3 \mathrm{H}, \mathrm{CH}_{3}, J=7.2\right.$
$\mathrm{Hz}), 1.73-1.79\left(\mathrm{~m}, 4 \mathrm{H}, \mathrm{C}_{5}-2 \mathrm{H}, \mathrm{C}_{6}-2 \mathrm{H}\right), 2.57-2.69\left(\mathrm{~m}, 4 \mathrm{H}, \mathrm{C}_{4}-2 \mathrm{H}, \mathrm{C}_{7}-\right.$ $2 \mathrm{H}), 3.94\left(\mathrm{~s}, 3 \mathrm{H}, \mathrm{OCH}_{3}\right), 4.25$ (q, $2 \mathrm{H}, \mathrm{CH}_{2}, J=7.2 \mathrm{~Hz}$ ), 7.27 (br., $1 \mathrm{H}$, $\mathrm{NH}), 7.70-8.39(\mathrm{~m}, 4 \mathrm{H}, \mathrm{Ar}-\mathrm{H})$. MS (EI, $70 \mathrm{ev}) \mathrm{m} / z(\%)=390\left(\mathrm{M}^{+}-\right.$ $\left.\mathrm{OCH}_{3}, 0.5\right), 387$ (4.1), 334 (1.9), 256 (0.2), 226 (10.1), 225 (70.7), 180 (20.3), 179 (100.0). Anal. Calcd. for $\mathrm{C}_{22} \mathrm{H}_{21} \mathrm{NO}_{5} \mathrm{~S}$ (411.11): C, 64.22; $\mathrm{H}$, 5.14; N, 3.40\%. Found: C, 64.26; H, 5.05; N, 3.47\%.

2-((3-Methoxy-1,4-dioxo-1,4-dihydronaphthalen-2-yl)amino)4,5,6,7-tetrahydro-benzo[b]thiophene-3-carboxamide (9b): Yield (0.52 g, 53\%); crystallization from ethanol; brown powder; m.p. $136^{\circ} \mathrm{C}$. IR (KBr): $v / \mathrm{cm}^{-1}=3342,3322,3271\left(\mathrm{NH}_{2}, \mathrm{NH}\right), 2931(\mathrm{C}-\mathrm{H}$, aliphatic), 1640, 1646, 1668 (3CO); ${ }^{1} \mathrm{H}-\mathrm{NMR}\left(200 \mathrm{MHz}, \mathrm{CDCl}_{3}\right) \delta$ (ppm): 1.74$1.97\left(\mathrm{~m}, 4 \mathrm{H}, \mathrm{C}_{5}-2 \mathrm{H}, \mathrm{C}_{6}-2 \mathrm{H}\right), 2.66-2.75\left(\mathrm{~m}, 4 \mathrm{H}, \mathrm{C}_{4}-2 \mathrm{H}, \mathrm{C}_{7}-2 \mathrm{H}\right), 3.91(\mathrm{~s}$, $3 \mathrm{H}, \mathrm{OCH}_{3}$ ), 6.18 (br., $\left.1 \mathrm{H}, \mathrm{NH}\right), 7.26$ (br., $\left.2 \mathrm{H}, \mathrm{NH}_{2}\right), 7.73-8.40(\mathrm{~m}, 4 \mathrm{H}$, Ar-H) $;{ }^{13} \mathrm{C}-\mathrm{NMR}\left(125 \mathrm{MHz}, \mathrm{DMSO}-d_{6}\right) \delta(\mathrm{ppm}) 183.2,180.9,167.5$, $160.3,155.8,134.8,134.5,133.2,131.8,120.3,120.0,117.5,116.4$, $116.0,112.0,55.9,22.1,23.3,23.7,24.1$ MS (EI, $70 \mathrm{ev)} \mathrm{m} / z(\%)=$ $382\left(\mathrm{M}^{+}, 0.2\right), 329$ (4.1), 302 (0.9), 255 (1.6), 224 (9.4), 192 (8.4), 187 (100.0). Anal. Calcd. for $\mathrm{C}_{20} \mathrm{H}_{18} \mathrm{~N}_{2} \mathrm{O}_{4} \mathrm{~S}$ (382.1): C, 62.81; H, 4.74; N, $7.33 \%$. Found: C, $62.85 ; \mathrm{H}, 4.68 ; \mathrm{N}, 7.35 \%$.

Synthesis of ethyl 2-((3-hydroxy-1,4-dioxo-1,4-dihydronaphthalen-2-yl)methyl) amino)-4,5,6,7-tetrahydrobenzo[b] thiophene-3-carboxylate (11): To a suspension of ethyl 2-amino-4,5,6,7tetrahydrobenzo $[b]$ thiophene-3-carboxylate $(6 \mathrm{a})(1.12 \mathrm{~g}, 5 \mathrm{mmol})$ in a mixture ethanol / acetic acid $(25 \mathrm{~mL}, 4: 1 \mathrm{~V})$ and 2-hydroxy-3((piperidin-1-yl)methyl)naphthalene-1,4-dione (10) (1.35 g, $5 \mathrm{mmol})$ was added. The reaction mixture was refluxed for $6 \mathrm{~h}$ then left to cool at room temperature. The obtained solid product was filtered off, dried and crystallized from ethanol to give compound 11 .

Yield $(0.82 \mathrm{~g}, 73 \%)$; crystallization from ethanol; brown powder; m.p. $>320^{\circ} \mathrm{C}$. IR $(\mathrm{KBr}): v / \mathrm{cm}^{-1}=3428$ (br., OH), $3280(\mathrm{NH}), 2935$ (C$\mathrm{H}$, aliphatic), 1712, 1664, 1659 (3CO); ${ }^{1} \mathrm{H}-\mathrm{NMR}\left(200 \mathrm{MHz}\right.$, DMSO- $\left.d_{6}\right)$ $\delta(\mathrm{ppm}): 1.35\left(\mathrm{t}, 3 \mathrm{H}, \mathrm{CH}_{3}, J=6.9 \mathrm{~Hz}\right), 1.68-1.90\left(\mathrm{~m}, 4 \mathrm{H}, \mathrm{C}_{5}-2 \mathrm{H}, \mathrm{C}_{6}-\right.$ $2 \mathrm{H}), 2.54-\left(\mathrm{s}, 2 \mathrm{H}, \mathrm{CH}_{2}\right), 2.47-2.60\left(\mathrm{~m}, 4 \mathrm{H}, \mathrm{C}_{4}-2 \mathrm{H}, \mathrm{C}_{7}-2 \mathrm{H}\right), 3.74(\mathrm{q}, 2 \mathrm{H}$, $\mathrm{CH}_{2} \mathrm{O}, J=6.9 \mathrm{~Hz}$ ), 7.50 (br., $\left.1 \mathrm{H}, \mathrm{NH}\right), 7.60-8.23$ (m, $\left.4 \mathrm{H}, \mathrm{Ar}-\mathrm{H}\right), 11.28$ (br., $1 \mathrm{H}, \mathrm{OH}) ;{ }^{13} \mathrm{C}-\mathrm{NMR}\left(125 \mathrm{MHz}, \mathrm{DMSO}-d_{6}\right) \delta$ (ppm) 183.0, 180.6, $167.3,160.1,156.2,134.6,133.3,132.2,131.6,129.9,125.7,120.5,119.2$ $115.6,113.1,62.3,45.1, .24 .1,23.7,23.3,22.1,15.0$. MS (EI, 70 ev) $\mathrm{m} / z$ $(\%)=413\left(\mathrm{M}^{+}+2,0.3\right), 360(12.5), 359$ (100.0), 340 (36.1), 330 (13.3), 314 (21.4), 313 (88.4), 257 (7.1), 200 (4.9), 188 (19.6), 174 (73.6), 146 (23.1), 118 (6.3), 99 (75.8), 98 (28.9), 82 (16.8), 73 (31.6). Anal. Calcd. for $\mathrm{C}_{22} \mathrm{H}_{21} \mathrm{NO}_{5} \mathrm{~S}(411.11)$ : C, 64.22; $\mathrm{H}, 5.14 ; \mathrm{N}, 3.40 \%$. Found: $\mathrm{C}, 64.28$; $\mathrm{H}, 5.08 ; \mathrm{N}, 3.36 \%$.

Synthesis of ethyl 2-((3,4-dioxo-3,4-dihydronaphthalen-1-yl) amino)-4,5,6,7-tetra-hydrobenzo[b] thiophene-3-carboxylate (12): A mixture of ethyl 2-amino-4,5,6,7-tetrahydrobenzo[b]thiophene3-carboxylate (6a) (1.12 g, $5 \mathrm{mmol}$ ) and sodium 3,4-dihydro-3,4dioxonaphthalene-1-sulfonate (1) $(1.3 \mathrm{~g}, 5 \mathrm{mmol})$ in a mixture of methanol / $\mathrm{H}_{2} \mathrm{O}(20 \mathrm{~mL}, 3: 1 \mathrm{~V})$ was refluxed for $1 \mathrm{~h}$. The reaction mixture was left to cool at room temperature and the formed precipitate was crystallized from ethanol to give compound 12 .

Yield ( $1 \mathrm{~g}, 98 \%)$; dark brown powder; crystallization from ethanol; m.p. $158^{\circ} \mathrm{C}$. IR (KBr): $v / \mathrm{cm}^{-1}=3270(\mathrm{NH}), 2931(\mathrm{C}-\mathrm{H}$, aliphatic), 1689 (CO), 1654 (2CO); ${ }^{1} \mathrm{H}-\mathrm{NMR}\left(200 \mathrm{MHz}, \mathrm{CDCl}_{3}\right) \delta(\mathrm{ppm}): 1.31$ (t, 3H, $\left.\mathrm{CH}_{3}, J=6.9 \mathrm{~Hz}\right), 1.77-1.92\left(\mathrm{~m}, 4 \mathrm{H}, \mathrm{C}_{5}-2 \mathrm{H}, \mathrm{C}_{6}-2 \mathrm{H}\right) ; 2.70-2.82\left(\mathrm{~m}, 4 \mathrm{H}, \mathrm{C}_{4}-\right.$ $\left.2 \mathrm{H}, \mathrm{C}_{7}-2 \mathrm{H}\right) ; 4.24(\mathrm{~s}, 1 \mathrm{H}, \mathrm{C}-\mathrm{H}) ; 4.27\left(\mathrm{q}, 2 \mathrm{H}, \mathrm{CH}_{2} \mathrm{O}, J=6.9 \mathrm{~Hz}\right) ; 6.77$ (br., $1 \mathrm{H}, \mathrm{NH}) ; 7.27-8.25$ (m, 4H, Ar-H); ${ }^{13} \mathrm{C}-\mathrm{NMR}\left(125 \mathrm{MHz}, \mathrm{DMSO}-d_{6}\right)$ $\delta(\mathrm{ppm}) 179.8,165.2,163.7,160.2,150.1,134.5,1330,132.3,132.2$, 130.2, 125.6, 125.5, 120.5, 115.7, 115.4, 113.3, 62.3, 25.1, 23.8, 23.5, $22,1,14.9$. MS (EI, $70 \mathrm{ev}) \mathrm{m} / z(\%)=381\left(\mathrm{M}^{+}, 0.3\right), 367(10.9), 336(1.6)$, 320 (18.5), 305 (4.6), 290 (2.2), 267 (2.2), 224 (71.4), 179 (18.9), 178 
(100.0), 160 (17.9), $150(34.0), 136(1.8), 130(8.3), 105(1.0), 84(7.9), 73$ (7.3). Anal. Calcd. for $\mathrm{C}_{21} \mathrm{H}_{19} \mathrm{NO}_{4} \mathrm{~S}(381.1)$ : C, 66.12; $\mathrm{H}, 5.02 ; \mathrm{N}, 3.67 \%$. Found: C, 66.16; H, 4.97; N, 3.71\%.

\section{Antioxidant activity}

ABTS screening assay: Antioxidant activity were evaluated from the bleaching of ABTS derived radical cations [16]. The radical cation derived from ABTS [2,2'-azino-bis (3-ethyl benzothiazoline-6-sulfonic acid)] was prepared by reaction of ABTS $(60 \mathrm{~mL})$ with $\mathrm{MnO}_{2}(3 \mathrm{~mL}$, $25 \mathrm{mg} / \mathrm{mL})$ in $(5 \mathrm{~mL})$ aqueous buffer solution ( $\mathrm{pH} 7)$. After shaking the solution for a few minutes, it was centrifuged and filtered. The Absorbance (A control) of the resulting green-blue solution (ABTS radical solution) was recorded at $\lambda_{\max } 734 \mathrm{~nm}$. The absorbance (A test) was measured upon the addition of $(20 \mathrm{~mL}$ of $1 \mathrm{mg} / \mathrm{mL})$ solution of the tested sample in spectroscopic grade $\mathrm{MeOH} / \mathrm{buffer}(1: 1 \mathrm{v} / \mathrm{v})$ to the ABTS solution. The inhibition ratio (\%) was calculated using the following formula:

\section{(\%) Inhibition $=[\mathrm{A}$ (control) $-\mathrm{A}$ (test) $/ \mathrm{A}($ control $)] \times 100$}

Ascorbic acid $(20 \mathrm{~mL}, 2 \mathrm{mM})$ solution was used as a standard antioxidant (positive control). Blank sample was run using solvent without ABTS (Table 1).

Bleomycin-dependent DNA-damage: The assay was done according to Aeschbach et al. [17], Chan and Tang [18] with minor modifications. The reaction mixture $(0.5 \mathrm{~mL})$ contained DNA $(0.5 \mathrm{mg} /$ $\mathrm{mL})$, bleomycin sulfate $(0.05 \mathrm{mg} / \mathrm{mL})$, and $\mathrm{MgCl}_{2}(5 \mathrm{mM}), \mathrm{FeCl}_{3}(50$ $\mathrm{mM})$ and the samples were dissolved in DMSO at concentration $(20$ $\mathrm{mL}$ of $1 \mathrm{mg} / \mathrm{mL}$ ). L-Ascorbic acid was used as a positive control. The mixture was incubated at $37^{\circ} \mathrm{C}$ for $1 \mathrm{~h}$. The reaction was terminated by addition of $0.05 \mathrm{~mL}$ EDTA $(0.1 \mathrm{M})$. The color was developed by adding thiobarbituric acid (TBA) $(0.5 \mathrm{~mL})(1 \%, \mathrm{w} / \mathrm{v})$ and $\mathrm{HCl}(0.5 \mathrm{~mL})(25 \%$, $\mathrm{v} / \mathrm{v})$ followed by heating at $80^{\circ} \mathrm{C}$ for $10 \mathrm{~min}$. After centrifugation, the extent of DNA damage was measured by the increase in absorbance at $532 \mathrm{~nm}$ (Table 2).

\section{Results and Discussion}

\section{Chemistry}

The target compounds were synthesized as outlined in Schemes 1, 2, 3 and 4. Detailed synthetic procedures for all compounds are described in the experimental section. Briefly, the starting compounds 2-methoxynaphthalene-1,4-dione (2), 2-hydroxynaphthalene1,4-dione (3), 2-bromo-3-hydroxynaphthalene-1,4-dione (4) and 2-bromo-3-methoxynaphthalene-1,4-dione (5) were prepared from sodium 3,4-dioxo-3,4-dihydronaphthalene-1-sulfonate according to the reported procedure $[19,20]$ (Scheme 1).

Scheme 1: Furthermore, 2-aminothiophenes 6a-c were prepared according to a reported procedure [21] and allowed to react with sodium nitrite in hydrochloric acid to produce the corresponding diazonium salts $7 \mathrm{a}-\mathrm{c}$ which coupled with compounds 2 or 3 (Nga and Dao, 2009) in pyridine to give the corresponding naphthoquinone derivatives 8a-e (Scheme 2).

Scheme 2: Structures of $8 \mathrm{a}-\mathrm{c}$ were confirmed on the basis of analytical and spectral data. The IR spectra of $8 \mathrm{a}-\mathrm{c}$ displayed absorption bands at $v=3446-3417,1673-1629$ and $1498-1452 \mathrm{~cm}^{-1}$ due to the stretching vibration of hydroxy, carbonyl and azo groups, respectively. In addition, the IR spectra of compounds $8 \mathrm{~d}$, e showed bands at $v=1714-1652$ and $1459-1454 \mathrm{~cm}^{-1}$ due to stretching vibration of carbonyl and azo groups, respectively. The ${ }^{1} \mathrm{H}$ NMR spectra of $8 \mathrm{a}-\mathrm{c}$ displayed characteristic signals at $\delta=1.71-1.90(\mathrm{~m}, 4 \mathrm{H}), 2.35-2.85$ ppm (m, $4 \mathrm{H}$ and 13.49-13.52 ppm (br, $1 \mathrm{H})$ due to cycohexene and

\begin{tabular}{|c|c|c|}
\hline Compound No & Absorbance of samples $(\boldsymbol{\lambda})$ & \% inhibition \\
\hline Control of ABTS & & $0 \%$ \\
\hline Ascorbic acid & 0.474 & $89.87 \%$ \\
\hline 8a & 0.048 & $6.23 \%$ \\
\hline 8b & 0.466 & $89.93 \%$ \\
\hline 8c & 0.050 & $27.96 \%$ \\
\hline 8d & 0.358 & $15.89 \%$ \\
\hline 8e & 0.418 & $25.55 \%$ \\
\hline 9a & 0.370 & $95.97 \%$ \\
\hline 9b & 0.020 & $79.47 \%$ \\
\hline $\mathbf{1 1}$ & 0.102 & $63.17 \%$ \\
\hline $\mathbf{1 2}$ & 0.183 & $65.59 \%$ \\
\hline
\end{tabular}

aATS: The method used for antioxidant activity

(\%) Inhibition $=[A($ control $)-A($ test $) / A($ control $)] \times 100$

Table 1: ABTS Antioxidant activity assay of compounds 8a-e, 9a,b, 11 and 12

\begin{tabular}{|c|c|}
\hline Compound No. & Absorbance of samples \\
\hline Ascorbic-acid & 0.097 \\
\hline $\mathbf{8 a}$ & 0.145 \\
\hline $\mathbf{8 b}$ & 0.098 \\
\hline $\mathbf{8 c}$ & 0.126 \\
\hline $\mathbf{8 d}$ & 0.138 \\
\hline $\mathbf{8 e}$ & 0.140 \\
\hline $\mathbf{9 a}$ & 0.082 \\
\hline $\mathbf{9 b}$ & 0.089 \\
\hline $\mathbf{1 1}$ & 0.093 \\
\hline $\mathbf{1 2}$ & 0.099 \\
\hline
\end{tabular}

Table 2: Bleomycin dependent-DNA damage of the investigated compounds.

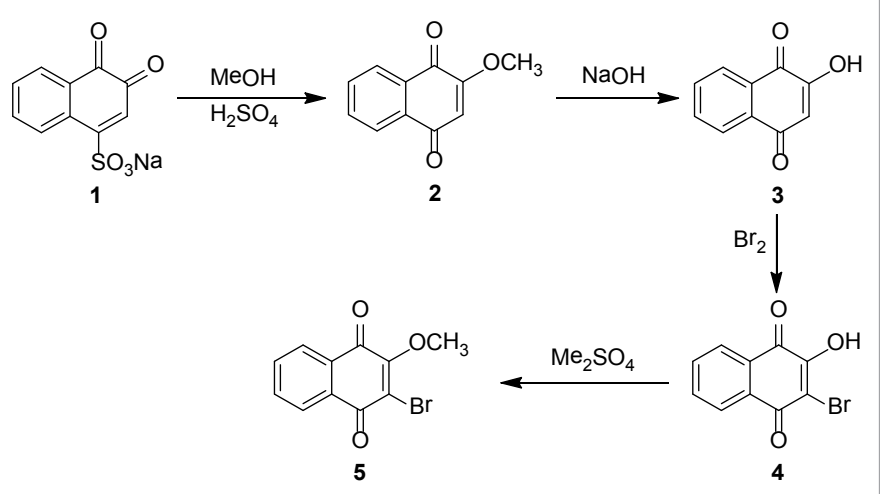

Scheme 1: Synthesis of 2-bromo-3-methoxynaphthalene-1,4-dione (5).

$\mathrm{OH}$ proton respectively. Furthermore, the ${ }^{1} \mathrm{H}$ NMR spectra of $8 \mathrm{~d}$ and $8 \mathrm{e}$ revealed singlet signals at $\delta 3.91$ and $3.86 \mathrm{ppm}(\mathrm{s}, 3 \mathrm{H})$ due to methoxy protons, respectively, in addition to cyclohexene signals at $\delta 1.52-1.85(\mathrm{~m}, 4 \mathrm{H})$ and $2.57-2.88 \mathrm{ppm}(\mathrm{m}, 4 \mathrm{H})$. The mass spectrum of 8 a showed the molecular ion peak at $m / z 408\left(\mathrm{M}^{+}-2\right)$ which is in agreement with the molecular formula $\left(\mathrm{C}_{21} \mathrm{H}_{18} \mathrm{~N}_{2} \mathrm{O}_{5} \mathrm{~S}\right)$, in addition to the base peak at $m / z 178$ which is related to $\mathrm{M}^{+}-\left[\mathrm{C}_{10} \mathrm{H}_{5} \mathrm{O}_{3}+\mathrm{OEt}\right]$ moiety. Also, the mass spectrum of $8 \mathrm{~b}$ displayed the molecular ion peak at $m / z 386\left(\mathrm{M}^{+}+5\right)$ which in agreement with the molecular formula $\left(\mathrm{C}_{19} \mathrm{H}_{15} \mathrm{~N}_{3} \mathrm{O}_{4} \mathrm{~S}\right)$, in addition to the base peak at $\mathrm{m} / z 345$ corresponding to $\left(\mathrm{M}^{+}-\left[\mathrm{H}_{2} \mathrm{O}+\mathrm{NH}_{2}\right]\right)$. Furthermore, the mass spectrum of $8 \mathrm{c}$ showed the molecular ion peak at $m / z 363\left(\mathrm{M}^{+}\right)$which is in agreement with the molecular formula $\left(\mathrm{C}_{19} \mathrm{H}_{13} \mathrm{~N}_{3} \mathrm{O}_{3} \mathrm{~S}\right)$ in addition to the base peak at $\mathrm{m} / \mathrm{z} 98$ due to thiophen-2-yl-methene moiety. The mass spectrum of $8 \mathrm{~d}$ showed two molecular ion peaks at $m / z 426\left(\mathrm{M}^{+}+2\right)$ and $424\left(\mathrm{M}^{+}\right)$ which are in agreement with the molecular formula $\left(\mathrm{C}_{22} \mathrm{H}_{20} \mathrm{~N}_{2} \mathrm{O}_{5} \mathrm{~S}\right)$ in addition to the base peak at $m / z 178$ due to $\mathrm{M}^{+}-\left[\mathrm{C}_{10} \mathrm{H}_{5} \mathrm{O}_{3}+\mathrm{OEt}\right]$ 


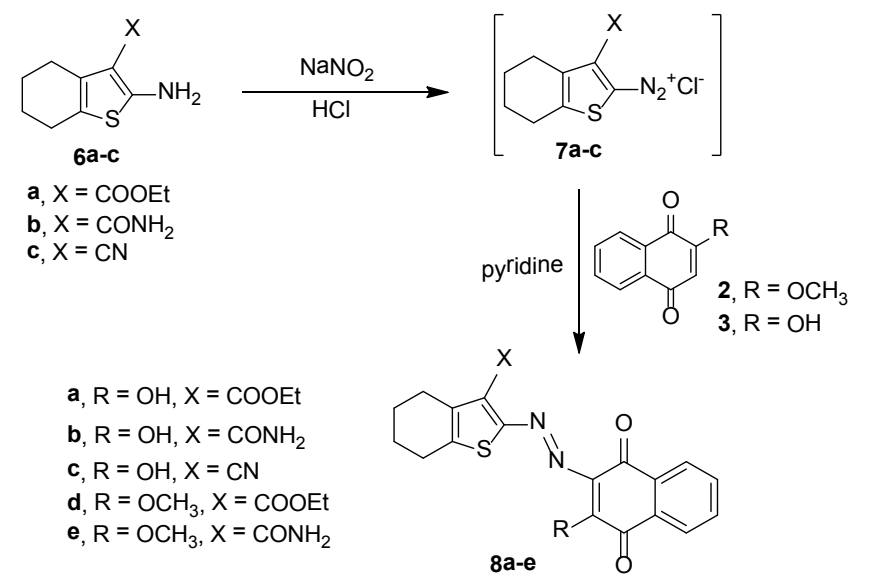

Scheme 2: Synthesis of 3-[(3-substituted-4,5,6,7-tetrahydrobenzo[b] thiophen-2-yl)diazenyl] naphthalene-1,4-diones 8a-e

moiety. Also, the mass spectrum of $8 \mathrm{e}$ showed the molecular ion peak at $m / z 394\left(\mathrm{M}^{+}-1\right)$ which is in agreement with the molecular formula $\left(\mathrm{C}_{20} \mathrm{H}_{17} \mathrm{~N}_{3} \mathrm{O}_{4} \mathrm{~S}\right)$ in addition to the base peak at $m / z 188$ corresponding to 2-methoxynaphthoquinone moiety.

Moreover, reaction of 5 with $6 \mathrm{a}, \mathrm{b}$ in ethanol containing potassium carbonate afforded the corresponding enaminnones $9 a, b$, respectively (Scheme 3). Structures 9a, b were elucidated based on analytical and spectral data. The IR spectra of $9 \mathrm{a}, \mathrm{b}$ showed absorption bands at $v=3297$ and $3271 \mathrm{~cm}^{-1}$ due to stretching vibration of $\mathrm{NH}$ groups, respectively. The ${ }^{1} \mathrm{H}$ NMR spectra of $9 \mathrm{a}$ and $9 \mathrm{~b}$ revealed signals due to cyclohexene at $\delta=1.73-1.97(\mathrm{~m}, 4 \mathrm{H})$ and $2.57-2.75 \mathrm{ppm}(\mathrm{m}, 4 \mathrm{H})$ and displayed signals at $\delta=3.91-3.94(\mathrm{~s}, 3 \mathrm{H})$ and $6.18-7.27 \mathrm{ppm}(\mathrm{br}, 1 \mathrm{H})$ due to methoxy and $\mathrm{NH}$ groups, respectively. The mass spectrum of $9 \mathrm{a}$ showed the molecular ion peak at $\mathrm{m} / z 390\left(\mathrm{M}^{+}-\mathrm{OCH}_{3}\right)$ which is equivalence with the molecular formula $\left(\mathrm{C}_{22} \mathrm{H}_{21} \mathrm{NO}_{5} \mathrm{~S}\right)$ in addition to the base peak at $m / z$ 179 due to 2-imino-3-carbonyl-tetrahydrobenzothiophene moiety. On the other hand, the mass spectrum of $9 \mathrm{~b}$ displayed the molecular ion peak at $m / z 382\left(\mathrm{M}^{+}\right)$which is in agreement with the molecular formula $\left(\mathrm{C}_{20} \mathrm{H}_{18} \mathrm{~N}_{2} \mathrm{O}_{4} \mathrm{~S}\right)$ in addition to the base peak at $\mathrm{m} / z 187$ that is related to 2-methoxynaphthoquinone moiety.

Scheme 3: Finally, heating of 6a with 2-hydroxy-3-((piperidn1-yl)methyl) naphthalene-1,4-dione (10) [22] in EtOH/AcOH or sodium 3,4-dihydro-3,4-dioxonaphthalene-1-sulphonate 1 in $\mathrm{MeOH} /$ $\mathrm{H}_{2} \mathrm{O}$ afforded the corresponding enaminones 11 and 12, respectively (Scheme 4).

Scheme 4: Structures 11 and 12 were assigned on the basis of analytical and spectral data. The IR spectra of 11 and 12 exhibited absorption bands at $3280-3270$ and $1712-1659 \mathrm{~cm}^{-1}$ due to stretching vibrations of $\mathrm{NH}$ and $\mathrm{CO}$, respectively, Furthermore, the ${ }^{1} \mathrm{H}-\mathrm{NMR}$ spectrum of 11 showed characteristic signals at $\delta 1.33\left(\mathrm{t}, 3 \mathrm{H}, \mathrm{CH}_{3}, J=\right.$ $6.9 \mathrm{~Hz}), 3.74\left(\mathrm{q}, 2 \mathrm{H}, \mathrm{CH}_{2} \mathrm{O}, J=6.9 \mathrm{~Hz}\right), 7.50(\mathrm{br}, 1 \mathrm{H}, \mathrm{NH})$, and 11.28 ppm (br, $1 \mathrm{H}, \mathrm{OH})$. Furthermore, the ${ }^{1} \mathrm{H}-\mathrm{NMR}$ spectrum of compound 12 revealed signals at $\delta 1.31\left(\mathrm{t}, 3 \mathrm{H}, \mathrm{CH}_{3}, J=6.9 \mathrm{~Hz}\right), 4.24(\mathrm{~s}, 1 \mathrm{H}$, $\mathrm{C}-\mathrm{H}), 4.27\left(\mathrm{q}, 2 \mathrm{H}, \mathrm{CH}_{2} \mathrm{O}\right)$ and $6.77(\mathrm{br}, 1 \mathrm{H}, \mathrm{OH})$. The mass spectrum of 11 showed the molecular ion peak at $m / z 413\left(\mathrm{M}^{+}+2\right)$ which is in agreement with the molecular formula $\left(\mathrm{C}_{22} \mathrm{H}_{21} \mathrm{NO}_{5} \mathrm{~S}\right)$ in addition to the base peak at $m / z 359$ due to $\left(\mathrm{M}^{+}-\left[\mathrm{EtOH}+2 \mathrm{H}_{2}\right]\right)$ fragment. Moreover, the mass spectrum of 12 displayed the molecular ion peak at $\mathrm{m} / z 381$ $\left(\mathrm{M}^{+}\right)$which is in agreement with the molecular formula $\left(\mathrm{C}_{21} \mathrm{H}_{19} \mathrm{NO}_{4} \mathrm{~S}\right)$ in addition to the base peak at $m / z 178$ that is related to $N$-ethenyl-2amino-tetrahydrobenzothiophene moiety [22].

\section{Biological evaluation}

Antioxidant activity assay: Ten thiophenes were screened for their antioxidant activity as reported [16]. The data showed clearly that compounds $8 \mathrm{~b}, 9 \mathrm{a}$ and $9 \mathrm{~b}$ exhibited good activities, while compounds 11 and 12 exhibited moderate activities compared with ascorbic acid. On the other hand, the rest of compounds exhibited weak activities (Table 1).

Bleomycin-dependent DNA-damage: Ten thiophenes were selected for bleomycin-dependent DNA-damage testing (Table 2). Damage of DNA in the presence of a bleomycin-Fe complex has been adopted as a sensitive and specific method to examine potential prooxidant agents [23]. If the samples to be tested are able to reduce the bleomycin $-\mathrm{Fe}^{+3}$ to bleomycin- $\mathrm{Fe}^{+2}$, DNA degradation in this system will be stimulated, resulting in a positive test for pro-oxidant activity. DNA degradation is accompanied by the formation of a product similar to malondialdehyde (MDA). L-Ascorbic acid was used as a reducing agent can reduce $\mathrm{Fe}^{+3}$ to $\mathrm{Fe}^{+2}$.

Results in Table 2 showed that compounds $8 b, 9 a, 9 b, 11$ and 12 have an ability to protect DNA from the induced damage by bleomycin. On the other hand, the rest of compounds exhibited weak activities. Thus,

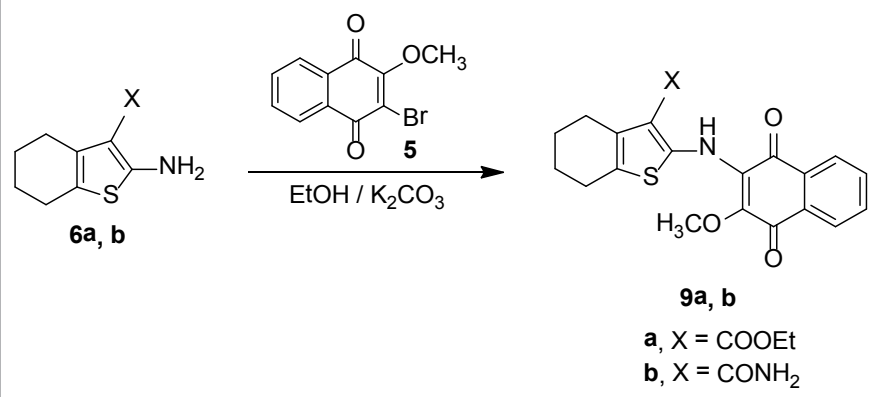

Scheme 3: Synthesis of 2-((3-substituted-4,5,6,7-tetrahydrobenzo[b] thiophen-2-yl)amino)-3-methoxynaphthalene-1,4-diones $9 a, b$.

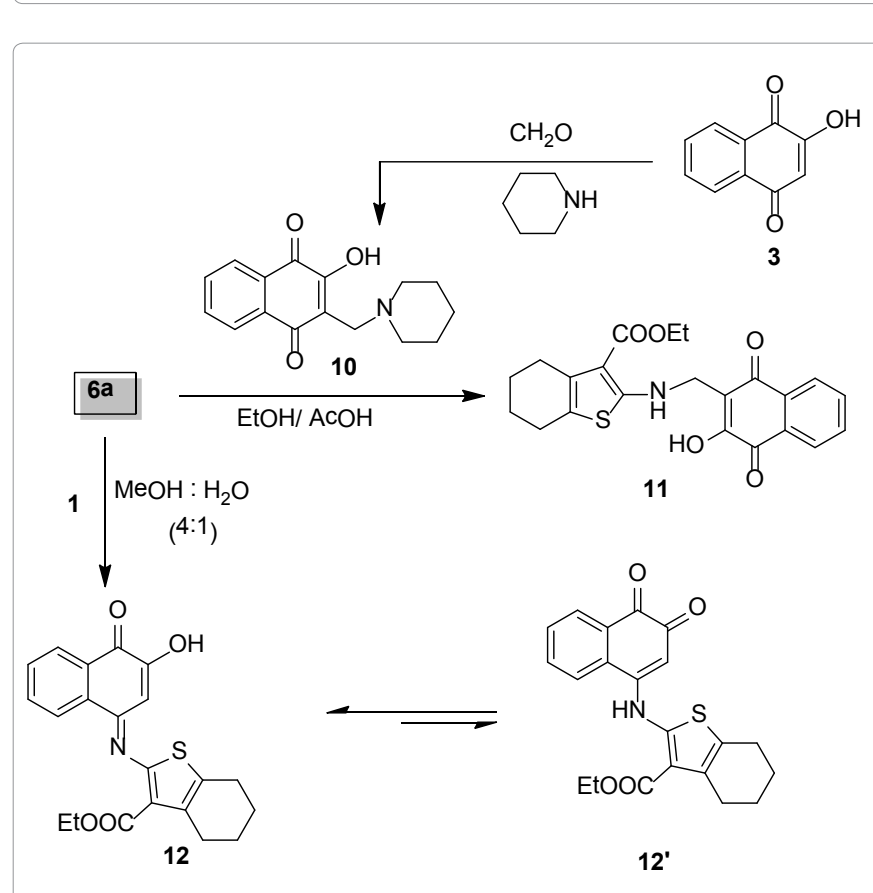

Scheme 4: Synthesis of ethyl 2-substituted-4,5,6,7-tetrahydrobenzo[b] thiophene-3-carboxylate derivatives 11 and 12. 
<smiles>COC(=O)C1=C(C#N)C(=O)c2ccccc2C1=O</smiles>

$8 b$<smiles>CCOC(=O)c1c(NCCNC2C(=O)c3ccccc3C(=O)C2O)sc2c1CCCC2</smiles>

11

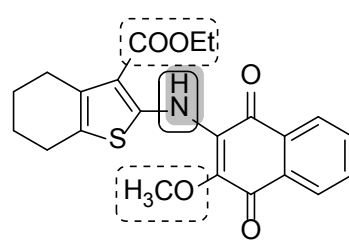

9a

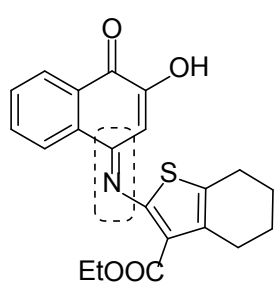

12
Figure 1: Structure activity relationship's (SAR's) of the more potent compounds.

it would appear generally that introducing of naphthoquinone moiety enhances the antioxidant properties of 2-aminothiophene compounds. By comparing the results obtained of the investigated compounds to their structures the following structure activity relationships (SAR's) were postulated: (i) naphthoquinones $8 \mathrm{~b}$ and $9 \mathrm{a}$ are more potent than 5 -florouracil (5-Fu) which may be attributed to the presence of thiophene and naphthoquinone moiety. (ii) Compound $8 \mathrm{~b}$ is less potent than 9a which may be due to replacement of $\mathrm{CONH}_{2}, \mathrm{OH}$ and $\mathrm{N}=\mathrm{N}$ moieties into COOEt, OMe and $\mathrm{NH}$, respectively. (iii) Compound 11 is more potent than the thiophene 9 a which may be attributable to the presence of $\mathrm{CH}_{2}$ moiety (iv) Compound 12 is more potent than 11 which may be due to the presence of $\mathrm{C}=\mathrm{N}$ moiety (Figure 1 ).

\section{Conclusion}

The objective of the present study was to synthesize and evaluate the antioxidant activity of some novel naphthoquinone derivatives with the hope of discovering new structure serving as antioxidant gent. The data showed clearly that compounds $8 \mathrm{~b}, 9 \mathrm{a}, 9 \mathrm{~b}, 11$ and 12 have the ability to protect DNA from the induced damage by bleomycin.

\section{References}

1. O'Brien PJ (1991) Molecular mechanisms of quinone cytotoxicity. Chem Biol Interact 80: 1-41.

2. Monks TJ, Hanzlik RP, Cohen GM, Ross D, Graham DG (1992) Quinone chemistry and toxicity. Toxicol Appl Pharmacol 112: 2-16.

3. Babula P, Adam V, Havel L, Kizek R (2007) Naphthoquinones and their pharmacological properties. Ceska Slov Farm 56: 114-120.

4. Kim BH, Yoo J, Park SH, Jung JK, Cho H, et al. (2006) Synthesis and evaluation of antitumor activity of novel 1,4-naphthoquinone derivatives (IV). Arch Pharm Res 29: 123-130.

5. Smith MT, Evans CG, Thor H, Sten O (1985) Quinones-induced oxidative injury to cells and tissues. In: Helmet, S. (Ed.), Oxidative stress. Academic Press Inc., London, 1-91.

6. Nikolakopoulos G, Figler H, Linden J, Scammells PJ (2006) 2-Aminothiophene3 -carboxylates and carboxamides as adenosine $\mathrm{A} 1$ receptor allosteric enhancers. Bioorg Med Chem 14: 2358-2365.

7. Ferguson GN, Valant C, Horne J, Figler H, Flynn BL, et al. (2008) 2-aminothienopyridazines as novel adenosine $\mathrm{A} 1$ receptor allosteric modulators and antagonists. J Med Chem 51: 6165-6172.

8. Souza BC, De Oliveira TB, Aquino TM, de Lima MC, Pitta IR, et al. (2012) Preliminary antifungal and cytotoxic evaluation of synthetic cycloalkyl[b] thiophene derivatives with PLS-DA analysis. Acta Pharm 62: 221-236.

9. Balamurugan K, Perumal S, Reddy ASK, Yogeeswari P, Sriram D (2009) A facile domino protocol for the regioselective and discovery of novel 2-amino5-arylthieno-[2,3-b] thiophenes as antimycobacterial agents, Tetrahedron Lett. 50: 6191-6195.

10. Fakhr IM, Radwan MA, el-Batran S, Abd el-Salam OM, el-Shenawy SM (2009) Synthesis and pharmacological evaluation of 2-substituted benzo[b]thiophenes as anti-inflammatory and analgesic agents. Eur J Med Chem 44: 1718-1725.

11. El Bialya SAA, Gouda MA (2011) Cyanoacetamide in heterocyclic chemistry: Synthesis, antitumor and antioxidant activities of some new benzothiophenes. J Heterocyclic Chem 48: 1280-1286.

12. Hamama WS, Berghot MA, Baz EA, Gouda MA (2011) Synthesis and antioxidant evaluation of some new 3-substituted coumarins. Arch Pharm (Weinheim) 344: 710-718.

13. Hamama WS, Zoorob HH, Gouda MA, Afsah EM (2011b) Synthesis and antimicrobial and antioxidant activities of simple Saacharin derivatives with $\mathrm{N}$-basic side chains. Pharm Chem J 45: 118-124.

14. Gouda MA, Abu-Hashem AA (2011) Synthesis, characterization, antioxidant and antitumor evaluation of some new thiazolidine and thiazolidinone derivatives. Arch Pharm (Weinheim) 344: 170-177.

15. Gouda MA, Berghot MA, Baz EA, Hamama WS (2011) Synthesis, antitumor and antioxidant evaluation of some new thiazole and thiophene derivatives incorporated coumarin moiety. Med Chem Res 21: 1062-1070.

16. Lissi EA, Modak B, Torres R, Escobar J, Urzua A (1999) Total antioxidant potential of resinous exudates from Heliotropium species, and a comparison of the ABTS and DPPH methods. Free Radic Res 30: 471-477.

17. Aeschbach R, Loliger J, Scott BC, Murcia A, Butler J, et al. (1994) Antioxidant actions of thymol, carvacrol, 6-gingerol, zingerone and hydroxytyrosol. Food Chem Toxicol 32: 31-36.

18. Chan TY, Tang PL (1996) Characterization of the antioxidant effects of melatonin and related indoleamines in vitro. J Pineal Res 20: 187-191.

19. Rafart H, Valderrama J, Vega JC (1976) Studies on quinones. I. The reaction of 2-hydroxy-3-(3-oxobutyl)-1,4-naphthoquinones and quinone analogs with secondary amines. (Inst. Quim., Univ. Catol. Chile, Santiago, Chile). An. Quim. 72(9-10): 804-8 (Spanish). C.A. (1977), 87: 151882m.

20. Nga ND, Dao TT (2009) Synthesis and of Lawsone (2-hydroxy-1,4 naphthoquinone) and methyl lawsone (2-methoxy-1,4-naphthoquinone). Vietnamese Pharm J 3: 29-32.

21. Gewald K (1965) Heterocyclen aus CH-aciden nitrilen, VII. 2-Amino-thiophene aus a-oxo-mercaptanen und methylenaktiven nitrilen. Chem Ber 98: 35713577.

22. Dam H, Glavind J, Karrer P (1940) Biological activity of the natural K vitamins and of me related compounds. Helvetica Chimica Acta 23: 224-233.

23. Gutteridge JMC, Rowley DA, Halliwell B (1981) Superoxide-dependent formation of hydroxyl radicals in the presence of iron salts. Detection of 'free' iron in biological systems by using bleomycin-dependent degradation of DNA Biochem J 199: 263-265. 